\title{
Strategies and Tactics of Communication in Parliamentary Discourse
}

SAL 36/2020

Strategies and Tactics of Communication in Parliamentary Discourse

Received 05/2019

Accepted 05/2020

\section{Parlamentinio diskurso komunikacijos strategijos ir taktika}

\section{LINGUISTICS / KALBOTYRA}

\section{Natalia V. Kondratenko}

Odesa National University by Mechnykov, Ukraine

\section{Anastasiia A. Kiselova}

National University Odessa Law Academy, Ukraine

\section{Liubov V. Zavalska}

National University Odessa Law Academy, Ukraine

\author{
crossef http://dx.doi.org/10.5755/j01.sal.0.36.23401
}

The study contains an outline of the results of linguo-pragmatic analysis of the speech behaviour of politicians who are participants of parliamentary discourse. The concept of parliamentary discourse is defined as one of the varieties of political discourse within the framework of institutional communication. The genre heterogeneity of political discourse is substantiated and the genre of debates, including pre-election and parliamentary debates, is defined. It is revealed that parliamentary debates mostly represent the linguo-pragmatic specificities of parliamentary discourse. The materials for the analysis consisted of transcripts of meetings of the Parliament of Ukraine in 2004-2019. The main criterion of the typology was the peculiarities of the observed communicative interactions: cooperative and conflict ones. Regulatory, informational and consolidation communication strategies are identified within the framework of cooperative communication; meanwhile, declarative, confrontational and argumentative-critical ones are identified within the framework of conflict interaction.

KEYWORDS: parliamentary discourse, communicative strategy, intention, communicative cooperation, communicative conflict, speech act.

Actualisation of an anthropocentric factor in linguistic research at the end of the $20^{\text {th }}$ and the beginning of the 21 st centuries has led to the emergence of a complex of interdisciplinary research focused on communicative activities of people. Linguistics' branches focused on the study of linguistic personality are actively developing as 'the linguistic personality becomes a peculiar dynamic combination of vast experience gained through collective action in real and communicative reality as well as in the reality of nonverbal thinking' (Bagautdinov et al., 2018, p. 38). This is largely reflected in linguo-pragmatic research focused on the analysis of the interactive communication and the conditions of its flow. The main issues of a linguo-pragmatic study of communicative activity were strategies and tactics of communication regarded as special models of human behaviour in different situations and conditions.

\footnotetext{
Introduction ktu

Research Journal Studies about Languages No. 36/2020, pp. 17-29 ISSN 1648-2824 (print) ISSN 2029-7203 (online)
} DOl.org/10.5755/j01.sal.0.36.23401 
The nature of the situation of communication predetermines the choice of not only linguistic means, but also the strategic direction, that is, it involves planning the implementation of the course of the interaction of the speaker with the addressee.

Consideration of the strategic aspect of communication is relevant to the various types of social interaction of communicants, but it gains the biggest importance in institutional communication, which is opposed to a personal one (Karasik, 2004) and is implemented in institutional types of discourse. One of the institutional discourses is considered to be political, the heterogeneous essence of which is defined by Sheigal: political discourse covers "any speech formations, which subject, addressee or content belongs to the sphere of politics" (Sheigal, 2004, p. 23). In the political discourse, communication strategies primarily depend on the peculiarities of the genre and the form of speech representation: the type of interaction is regulated by the conditions of discursive activity, so communicants use specific communicative strategies in their oral political statements, political advertising or political interviews. Each manifestation and genre of political discourse in the strategic aspect is based on a set of definite models of role-oriented communicative behaviour of speakers-politicians.

Among the varieties of political discourse, a special role belongs to the parliamentary discourse, the main manifestation of which is the parliamentary debate (Baranov and Kazakevich, 1991). In Ukrainian political communication, parliamentary debates are represented by the sessions of the Parliament of Ukraine where lawmaking activities of politicians take place and important issues of political life are discussed. The chairman of the meetings is the Speaker of the Parliament or his deputy, who acts as a moderator in parliamentary debates: announces the agenda, gives the floor, sums up, and so on. Participants of parliamentary debates talk in turn: for the most part, the topic of discussion is proposed by one politician who represents the bill, and deputies criticise or support his speech. Controversial and cooperative strategies of interaction of politicians - participants in parliamentary discourse - are presented during the debate.

The purpose of the scientific reasearch is to outline communication strategies and tactics in parliamentary discourse on the basis of a linguo-pragmatic analysis of politicians' speach. At the same time, the communicative strategy is interpreted as a general scheme of deployment of speech interaction, the vector of achievement of communicators' intention, which is realised through specific speech techniques - communicative tactics. Tactics are understood as ways of implementing selected strategies, presented in speech primarily by speech acts and texts. The focus of the study was on the linguistic means of realising the intentions of participants in parliamentary discourse (vocabulary, expressions, texts).

The scientific interest in the study of the strategies and tactics of parliamentary discourse is explained by the need for a linguo-pragmatic interpretation of political communication that takes into account the pragmatic guidelines of the speakers, the models of speech behaviour and the specifics of the speech acts used. The main attention is focused on the communicative strategies of politicians presented in the Ukrainian parliamentary discourse as linguistic individuals involved in the debate, engaging in discussions with each other. The source of the research was transcripts of parliamentary debates, which were made public on the official website of the Parliament of Ukraine from 2004 to 2019.

Theoretical Research Basis
The study of parliamentary discourse is closely related to the study of the varieties of political communication, which is substantiated in the writings of foreign researchers of political linguistics (Dijk, 2015; Vodak, 1997; Chudinov, 2009). The linguists mostly focus on questions of methods and determining parameters of political communication, language units of different levels operating in the political sphere, genres and types of political texts, strategies and tactics of communication in political discourse, etc. Recently, the heterogeneous structure of political discourse determining the isolation of various discursive formations within its boundaries - advertising, propaganda, ritual, parliamentary ones - has attracted attention. First, 
these varieties of political discourse differ in the sphere of representation and communicative guideline. The parliamentary discourse is characterised by representation through parliamentary debates, which are aimed at discussing issues relevant to society and approving laws.

Linguistic research devoted to parliamentary debates actualises the role of the speakers in communicative interaction: "The discursive interaction of parliamentarians is determined by their institutional role commitments, the dialogical form of institutional confrontation and the awareness of acting in front of and at the multilevel audience" (Matveeva, 2016, p. 133). The institutional nature of parliamentary discourse involves consideration of the strategic aspect of the analysis.

The research of the discourse of parliamentary debate is primarily based on a communicative-discursive approach. Pjetcuh defines parliamentary debate as "a complex communicative event, which takes place in the form of a gradual deployment and with a clear set of temporal and thematic boundaries of discussion, involves the involvement of a large number of communicants - politicians who have clearly defined status-hierarchical roles and enter the discursive field of debate, uniting on the basis of common interests and solving the socio-political issues they discuss" (Pjetcuh, 2018, p. 46).

However, the most relevant aspect of the study of parliamentary discourse is a linguo-pragmatic one, namely analysis of communication strategies and tactics. The notion of a communicative strategy and tactics as its implementation is described in the writings of Issers (2008), Yanko (2001), and others. For the most part, researchers agree that strategies are a way of solving a global communicative task, and tactics are local tools to achieve strategic goals. In the political discourse, communication strategies and tactics are regarded on the basis of political speech as a verbal representation of the linguistic personality of politicians (Parshina, 2004). Parliamentary discourse is a complex communicative process, mostly polylogic, implemented through specific strategies and tactics.

The research is methodologically based on the communicative-pragmatic approach to the study of linguistic phenomena: interaction as a unit of communication, presented within the framework of institutional communication in the political parliamentary discourse, is the focus of attention. The inductive method, characterised by obtaining general conclusions through a generalisation of the features of certain subjects and situations, represents the general scientific methods used in the study of strategies and tactics in the parliamentary discourse, as well as the method of observation that included work with the texts of the transcripts of the meetings of the Parliament of Ukraine. Among the special linguistic methods, discourse analysis was used to study interactive communication in the institutional communication of politicians, which involved studying the monological speeches of politicians in the Parliament of Ukraine and political communication while discussing problematic issues. Functional analysis was used to determine the peculiarities of the functioning of linguistic units in parliamentary discourse, and in particular, the basic functions of lexical and grammatical units of language used to verbally influence the audience were studied. Interpretive analysis was used for the development of the author's concept based on linguo-pragmatic interpretation of communicative interaction as a result of influencing and directing speech behaviour of communicators. Linguo-pragmatic analysis was employed to describe the strategies and tactics of communication, paying attention to the anthropocentric factor and highlighting the author's guidelines and tasks.

Ukrainian parliamentary discourse is a complex discursive formation with the purpose to discuss issues of political life of the country and the legislation. The process of discussion is subordinated to the general guidelines of parliamentary discourse, implemented through
Methodological Basis 
appropriate strategies of speech behaviour of politicians. In political speech, strategies are defined in the following way: "Under the political media speech, we understand the whole complex of speech acts carried out to realize the goals of the political dialogue in the mass media" (Zheltukhina et al., 2018, p. 650). For parliamentary debates, a communicative strategy is defined as a "line of behavior of the speaker with the intention to reach a definite goal and to make a significant impact on the recipient by the appropriate choice of the most effective linguistic means" (Belova et al., 2016, p. 54). The definition of parliamentary discourse strategies correlates with the identification of strategies in political discourse in general. Taking this into consideration, Mihaliova distinguishes three strategies of communication in political discourse: "the strategy for the fall, the strategy on the rise and the strategy of theatricality" (Mihaliova, 2009, p. 45). Other researchers suggest separating "destructive and constructive types of communication" (Belova et al., 2016, p. 54) in parliamentary debates. We rely on the distinction between the two main types of communication, i.e., conflict and cooperative ones, which determines the proposed approach to defining strategies for communicators' interaction in parliamentary debates.

Accordingly, in the parliamentary discourse we distinguish two types of communicative interaction: conflict and cooperative ones. We analysed the transcripts of the Parliament of Ukraine during the last 15 years (2004-2019) and identified the main strategies of communication in the parliamentary discourse.

1. Cooperative strategies are aimed at achieving success in communication, are subordinated to the implementation of a common communication task and are designed to be effective. The participation of each interlocutor should be subordinated to the common goal of communication and be guided by the behaviour of another interaction participant (Grice, 1967). In parliamentary discourse, cooperative strategies are designed for a productive discussion of political and legislative issues, the achievement of agreement between deputies, and effective decision-making. These strategies (including regulatory, informative and consolidating ones) are based on communication maxims aimed at achieving cooperation.

$1 A$. The regulatory strategy determines the procedure for parliamentary hearings and debates and manages the members of parliamentary discourse. The socially deterministic roles performed by politicians during the Parliament sessions are determined by the rules of parliamentary meetings: moderating by the chairman of the meeting, alternating speeches, limiting the length of speeches, respecting other participants, etc. In case of violation of these rules, the right of speech is canceled first and foremost: the microphone is turned off in order to deprive the speaker of the opportunity to voice their position.

Mostly, the regulatory strategy is implemented in the speech behaviour of the Parliament's Speaker, who acts as the moderator of the meeting, for example:

Dear colleagues, I would like to emphasise that we have one hour allocated. The factions provided their written questions. I gave each faction the guaranteed right to ask one question. There will be no more questions (Chairman of the meeting, 12.12.2014).

The main functions of the chairman of the meeting are to provide the right to speak to the deputies, to verify their compliance with the requirements for speaking, to formulate and note the rules of communicative interaction, for example:

In accordance with the Rules, I have the right to put forward draft resolutions on the abolition of decisions at any stage (Chairman of the meeting, 17.01. 2019).

The verbal form of presentation of the communicative position of the chairman of the meeting is $1^{\text {st }}$ person singular, that is, the head speaks on his behalf although he is not named 
in the transcripts of the Parliament session (it is only at the beginning of the transcript that the chairman of that day's meeting is indicated). This way the emphasis is placed on the domination of the social function in the position of the speaker, rather than on his subjective opinion: the chairman here is not a representative of a certain political force (party, faction), but fulfills the social role of the moderator of parliamentary discourse. In this regard, he does not comment and evaluate the content of speeches, but monitors the implementation of formal requirements - the rules of communication. The chairman draws attention to the topic of speech, duration and ethics, which implies the use of regulatory speech acts, for example:

Dear colleagues, I must note that there has just been a gross violation of the Rules of Procedure of the Verkhovna Rada of Ukraine because the rejected amendment can only be presented by its author (Chairman of the meeting, 20.03.2019).

At the linguistic level, the characteristic feature of this strategy is the interactive nature determining the use in the chairman's speech of direct addresses and grammatical forms of the $2^{\text {nd }}$ person that indicate the direct addressees of the speech. The main addressee is the collective one, i.e., the deputies present in the meeting room in the communicative space with the speaker, for example:

Dear colleagues, let's do it like this: I will now put it to a vote - and we will determine this matter by voting (Chairman of the meeting, 28.12 .2014).

The basis of the speech activity of the chairman of the meeting consists of the verbalisation of each communicative step and the explication of compliance with regulatory requirements. The dialogic nature of communication within the regulatory strategy does not actualise the verbal activity of the recipients, but determines their direct behaviour during the meeting, i.e., it has a perlocative force. With this in mind, the use of performers of different types is frequent within the limits of this strategy, for example:

I ask everyone to go to the hall to take their seats. Head of factions, invite deputies to the hall (Chairman of the meeting, 7.02.2018); 344 deputies are registered. I declare the morning plenary meeting of the Verkhovna Rada of Ukraine open (Chairman of the meeting, 13.03.2019);

I give the word to the deputy Maxim Bourbak (Chairman of the meeting, 20.03.2019).

First of all, directive speech acts aimed at encouraging the addressees to perform certain actions are used, and this is the main function of the communicative behaviour of the chairman of the meeting. Moderation by the chairman of the meeting is carried out in accordance with the specified protocol norms and is subject to the achievement of the common cooperative goal, hence the determination of the speakers (both the chairman and the participants) to follow the rules of communication in parliamentary discourse, for example:

... please do not violate the rules of procedure, let it go to the committee, the committee will consider it, and then we will vote and we will put it on the agenda (0. Kozhemyakin, 6.11.2009).

In this case, politicians-speakers perform the function of regulation in a meeting, taking over the responsibilities of the chairman. This also holds true if the chairman does not perform his functions at the proper level or in full.

The regulatory strategy is largely determined by the ritual nature of communication in parliamentary discourse: the correspondence of communicative roles and behaviour patterns to the communication participants also determines the need for compliance with protocol rules of speech interaction. 
1B. The informative strategy is aimed at informing participants of the Parliament meetings about new and operational information. Information is provided in the form of a beforehand prepared monologue summarising previous discussions outside of the parliamentary meeting. First, this is relevant in situations of discussion of bills submitted to the relevant committees for consideration through representatives-deputies. In this case, the discussion part is omitted, and only the information processed for final acceptance is presented. Under these conditions, the speakers report on the results of the work of the committee, i.e., they report to other deputies, for example:

I inform you that the Budget Committee continues to work on the President's remarks to the Budget Code (0. Lyashko, 04.09. 2009);

Once again I want to inform, I am very grateful to you for the fact that our amendment was actually taken into account (V. Nimchenko, 20.03.2019).

The reported information is presented to the deputies as well as for further discussion if the issue is problematic. In the framework of the informative strategy, addressees are addressed in order to report operational or new information on legislative activity of the Parliament.

The basic instruction of the speakers here is informing, but the strategic plan is aimed at the conviction and argumentation of other members of the parliamentary discourse in support of the position presented by the speaker as a collective opinion of the committee, for example:

The Budget Committee considered the draft law and concluded that it would not have negative influences on the revenue side of the budget (0. Bilorus, 17.11.2010);

The bill prepared on the basis of decisions of the European Court of Human Rights, agreed with the ministries, is absolutely correct (M. Knyazhitsky, 17.01.2019).

The speaker here speaks on behalf of the collective subject, reporting the results of the collective work. He is just an authorised person who informs members of the parliamentary discourse of the necessary information, even though if presenting it in an optimised way. Such an announcement is preceded by the discussion of bills in corresponding committees, so deputies receive information in the processed form: inaccuracies are eliminated, problematic issues are coordinated. In this regard, informing is carried out in order to persuade support for the proposed bill.

The informative strategy entails active citation, references to sources and known facts, for example:

The average wage, the share of wages in the cost price of products, which is produced in Ukraine, is 6 percent (S. Kaplin, 05.09.2018);

France is a country that is compatible with Ukraine in terms of potential, area, territory, population: education is free from two years and until the end of the university (P. Pschenka, 3.10.2018).

These facts serve as an illustration or a basis for expressing a certain opinion; politicians report well-known things by demonstrating their own education. Through this, the information strategy is realised through the tactics of intellectualisation, which involves the representation of their own intelligence.

Among the speech acts for the implementation of the informative strategy prevails the representations capturing the main provisions of the bills under discussion, for example:

The Convention is aimed to create the conditions necessary for the development of cultures of national minorities, namely: the protection and promotion of forms of cultural 
expression, the creation of conditions for the free interaction of various cultures and the promotion of intercultural cooperation (T. Kochan, 20.01.2010);

This bill proposes, first of all, to regulate the use of the housing stock in such a way that the majority of inhabitants of the corresponding house lived in a quality manner, did not suffer from their neighbors every day in their own home (Y. Levchenko, 4.12.2018).

At the same time, the speaker does not retell the content of the bills, but comments on them, actualising the main content aspects: his task is to summarise the concept of bills, a list of discussion points and arguments of the position of those who created or will support the bill.

1C. Consolidating strategy has a pronounced cooperative nature since it is focused on a demonstration or a call for joint productive work. Here we distinguish two forms of consolidating implementation: first, the pursuit of the common unity of people and politicians; second, expressing support to specific participants in parliamentary discourse and relevant bills.

In the first case, for the most part, we are talking about the speeches of deputies characterising the political situation in the country, for example:

I emphasise once again that we are united and together solve these common issues, or that continuing mess will destroy our entire state (0. Danilov, 12.07.2007).

In this case, politicians are calling for collaborative work and effective lawmaking, but the implementation of this strategy has a generalised character. The presence of pro-government political forces and opposition in the Parliament requires constant calls for unity in order to improve the country's life. It is presented within the framework of the first manifestation of the consolidating strategy.

This type of presentation of the consolidating strategy is due to the conflict of political discourse, its agonistic nature, i.e., the lack of a common opinion in the adoption of important decisions for the country requires some use of communicative efforts to reach a compromise. The presence in the Parliament of the pro-government and opposition forces determines the latent confrontation, but the adoption of bills necessary for the effective work of the state is a prerequisite for their joint work.

In the second case, the consolidating strategy is implemented at the level of discussion of specific bills: the deputies either speak out to criticise the proposals or agree with them. Consolidating implies support for the speeches of previous speakers, for example:

We all support the fact that the regions have an additional impetus for development (I. Kirilenko, 08.07.2008);

I ask deputies to consolidate around this bill; it is very important because mediation as a pre-trial settlement of disputes allows us to solve many problems (0. Ryabchin, 28.02.2019)

For the parliamentary discourse, the second case is more important because it demonstrates the achievement of agreement among deputies regarding particular result of lawmaking, for example:

Certainly, our faction will support this bill in the first reading (V. Tarasov, 10.04.2007);

Undoubtedly, our faction will support this resolution because the words of unity and catholicity are key to the Ukrainian state and for the Ukrainian statehood (I. Mosiychuk, 05.09.2018).

There is an expression of double consolidation: on the one hand, the speaker expresses the consolidated position of his faction, and on the other hand agrees with the authors of the bill. In addition to the collective position, deputies express their own thoughts on the issues discussed, for example: 
Therefore, I sincerely thank the author for timeliness, a thorough law, the legally correct, complete law. And I think that it can be adopted not only in the first reading, but also in general (K.Vaschuk, 14.01.2011);

I absolutely agree with you that the opinion of the residents must be present, but a legislative instrument must be given (A. Shinkovich, 04.12.2018).

The communicative purpose of the speaker in both cases is to support the proposed bill. At the same time, the argument of the consolidated position is minimal: deputies point out that it is not necessary to adopt the law without comments although commenting on its main positive features, for example:

I am calling, let us, by voting for this amendment, as it is sensible and concerns the assessment of land, fees for the land, and these funds go to the land, and not extract the last fertility (S. Ryzhuk, 14.01.2010).

The speakers not only agree with the draft bill, but also urge other members of the parliamentary discourse to support it, uniting everyone around a particular problem.

2. Conflict strategies are characterised by a lack of willingness for a common result, opposing positions of participants in interaction and demonstration of verbal aggression. However, conflict interaction is the engine for the adoption of constructive decisions because as a result of disputes, the interlocutors exchange views, take into account each other's arguments and reach a certain degree of agreement. In the parliamentary discourse, conflicts are the natural state of communicative interaction, they reflect the different views of major political forces on problem issues. According to Selina, conflicts in the parliamentary discourse have horizontal and vertical manifestations: they are divided into conflicts of interest between individual parliamentarians (interpersonal conflicts) and conflicts between representatives of certain groups of interests, and on other levels, the status and constitutional-legal conflicts are implemented (Selina, 2014). In the Ukrainian parliamentary discourse, conflicts occur between political opponents, primarily in the discussion of complex, controversial issues. Within the framework of conflict interaction in the parliamentary discourse, we distinguish the declarative, confrontational and argumentative-critical strategies.

2A. The declarative strategy is subordinated to the function of self-presentation of a political entity: instead of effective discussion and decision-making, politicians comment on their own position and demonstrate image characteristics, for example:

Ukraine now more than ever needs serious, well-considered decisions, and especially the unity of all branches of power and political forces (I. Kirilenko, 15.04.2008);

But the consideration of this issue in the current Ukrainian realities is cynicism. It's just cynicism! Why? Because there is no justice (I. Mosiychuk, 4.12.2018).

The communicative conflict here is expressed in the absence of a common result, in the declarative manner of a critical position the purpose of which is to deny the positions of other political forces. In this case, the speakers resort to the use of arguments that are universal in nature, but are not suitable for confirming or denying the opinion in a particular speech situation. In this regard, we document the statements of politicians containing declarative statements, truisms, calls for joint work and cooperation, etc. However, there are no specific proposals and constructive criticism. The declarative strategy is a kind of advertising for politicians who are demonstrating their own concern about the fate of the country, for example:

The best policy in times of crisis is to be honest with its people, tell them the truth and explain what difficult steps will be undertaken and what they will lead to (I. Yeremeyev, 23.12.2014). 
Instead, there is no specific or new information in these; politicians mostly express the thesis of the advertising manner. We believe that the actual addressee of such statements is not those present in the session hall of deputies, but voters who have supported or will support the corresponding deputy in the future.

Such a controversial behaviour is primarily characteristic of opposition politicians who criticise the work of the current government, for example:

The authorities have completely lost their conscience: they are hiding behind the slogans about a strong army, but in fact we see them stealing from it (0. Vilkul, 27.02.2019).

We do not notice that today we have the most shameful election campaign. People are now trading what they can, the power sells everything it wants (N. Shufrich, 13.03.2019).

Expectations of the recipients in this case are confirmed: an appeal to moral and ethical norms combined with negative assessments of the activity of power is positively perceived by a part of the recipients. The linguistic acts used are the representations that contain the fixation of the habitual state of things and the reporting of a particular reality situation. In this case, the declarative performance is enhanced by emotionality and expressiveness. Hence, the use of rhetorical questions, for example:

I would ask you to think about what you are sitting here. In order to be engaged in politics? In order to brag on the screens about who helped people more? In order to criticise the government ... because the government has little help to our citizens? (R. Zvarych, 29.11.2009).

The declarative strategy is used primarily by populist politicians who appeal to ethical principles, call for unity for the sake of the people, reminiscent of all known truths, but do not offer any real steps for solving problems. For such politicians, their main tools are wordiness, aphoristic way of thinking and frequent use of oratorical methods of influence on the audience, for example:

In fact, we have a significant day today. Today, we have to vote with you on the key law for the present - the law on peace, the law on the strategy of reforms, the law on our place in Western civilisation (Y. Tymoshenko, 23.12.2014);

I want to appeal to all of us and to remind that we are living with you not on the globe of Ukraine (O. Syroyd, 20.03.2019).

Such expressions contain verbal expression markers and increased manipulative potential but are uninformative in their content.

2B. Confrontational strategy is to a large extent a representation of conflict interaction as it involves destructive communicative behaviour of speakers, discrediting interlocutors, lack of a common communicative task and willingness to have a common result of communication. However, in the Ukrainian parliamentary discourse, this strategy is unpopular since the participants of the interaction are oriented towards a common communicative goal - the adoption of laws and the achievement of consent. Only certain communicative situations unfold in a conflict plane. First, this policy is used by politicians of opposing ideological positions addressing their opponents, for example:

You should not annoy us, or you will have to recall your combat future and give a worthy rebuff to those so-called politicians who, pushing the fire of the civil war, lead to the death of our state (C. Chervonopysky, 14.03.2007);

It is unprofessional, it does not make any sense at all for the development of Ukraine's education (0. Spivakovsky, 21.09.2018). 
At the same time, not the confrontation itself is dominant, but its flasal demonstration, which does not allow the speaker to name their political opponents, and their speech has no addressee. However, this does not prevent the use of tactics of accusations and the threat to the collective addressee, i.e., deputies of the opposite political position, for example:

For the last 4 years, you have destroyed the country, and now you spread the pathetic (V. Lytvyn, 05.09.2018); Either you will bring order, or I will put you all in jail for what you are doing now (0. Lyashko, 01.03.2019).

The communicative conflict is mostly focused on the normativity of the speaker's own position, which is supported by the criticism of other participants in communication. This depersonalisation is observed in the expression of the strategy of confrontation, regardless of the political force and its representatives, because here the main intention of the speaker is criticism and humiliation of other participants in the debate, for example:

... the author of the bill from the opposition, being at the rostrum, did not say a word about the meaning the law, just insulted and went away (P. Tsibenko, 12.01.2011).

In this regard, their actions are negatively evaluated using a stylistically reduced and invective vocabulary.

We consider the omission of the speech addresse the specific feature of the implementation of the confrontational strategy in the parliamentary discourse: the speaker expresses general criticisms, disagreeing with the opposite position, but rarely points to the person with whom the conflicts interact. In this regard, one of the main tactics of confrontation is denial, for example:

And so, we categorically deny this bill (N. Korolevskaya, 04.12.2018).

Mostly, it is a conditional political opponent who is the bearer of a definite, opposite ideology. However, there are isolated cases of addressed confrontation, for example:

Perhaps this is one more disappointing mistake of yours, Arseniy Petrovich (N. Shufrich, January 18, 2008).

In this case, the confrontation has a tolerant expression, with the support of the tactics of cooperative interaction, but expresses the hidden criticism of the opponent.

2C. An argumentative-critical strategy characterises rational speech behaviour, directed not on the agreement with the interlocutor but on criticising them or denying their words. Unlike cooperative strategies, the argumentative-critical one is not focused on solving a common communicative problem: the speaker explains and comments on their own point of view, which is different from what was said earlier, for example:

Today, various political forces are trying to give self beneficial explanation of this situation. I would like to touch on a few objective things that can not leave us indifferent to the current situation (0. Moroz, 20.07.2006);

The draft law, in our point of view, focuses not on the development of forms of cooperation between the state and business, but on improving the efficiency of the criminal function of the state (R. Semenukha, 04.12.2018).

This strategy is based on the basic rules of proof and argumentation while the speakers use the basic logical principle of argumentative speech. Arguments are convincing facts, generally accepted information, which all participants agree on. Speech is mostly emotionally neutral, without the use of stylistically marked vocabulary or expressive syntactic designs. 
Politicians demonstrate argumentative thinking relying on the basic rule of proof: they formulate the thesis, a set of arguments, and use the basic forms of reasoning. Refutations are used along with proofs, for example:

Article can not be called "Right to language" because there is no such right at all. Not the language itself is the subject of rights and duties, but its use and application can be regulated, and the law may impose duties on the use of the language (M. Knyazhitsky, 13.03.2019).

It also provides for the presentation of appropriate arguments. The most common forms of refutations are arguments and thesis criticism.

True judgments such as convincing facts, authoritative thoughts, general information serve as arguments, for example:

Top economists of the world warn Ukraine: if you sell the land, you will not be able to buy the goods produced on this land (V. Galasyuk, 17.01.2019).

Individual methods of verbal influence, which include references to authority and appeal to historical examples, are also used among the arguments, for example:

Weimar Republic was destroyed by the lack of institutional legal continuity. Maybe in Ukraine one should take into account mistakes of others (V. Leschenko, 24.02.2007).

Such techniques are incorrect in terms of logical rules of conduct of argumentation, but in parliamentary discourse, they predominate: arguments to the person, to physical strength, to authority, etc.

Under these conditions, politicians' statements have inductive and traductive considerations that suggest probable conclusions, for example:

Here, look, our colleagues who chose the European choice, say, let's move to tomorrow, because this is an important decree. So, let's transfer the payment of wages to deputies who do not go to the hall today to the day after tomorrow (I. Shurma, 06.02.2019).

This example demonstrates an analogy that has the character of manipulation and is used for the purpose of reasoning-critical influence on the recipients. The given strategy on the formal side is an expression of a rational-logical approach to communication, and on the other hand, manipulative-critical; therefore, it belongs to the conflict.

The result of the research is the development of a typology of communicative behaviour strategies in the parliamentary discourse. Based on the criterion of the chosen type of communicative interaction, cooperative and conflict strategies are defined. The cooperative one includes regulatory, informative and consolidating strategies. The regulatory strategy is subordinated to the application of procedural rules and regulations during the parliamentary debate, the informative strategy provides for the notification the participants in the parliamentary discourse of the new and operational information, and the consolidating strategy points to the need for the association of communicators or politicians and people. Among the conflicts strategies, declarative, confrontational and argumentative-manipulative ones are identified. The declarative strategy is typical for the self-presentation of populist politicians who appeal to general moral and ethical values, the confrontational strategy provides for targeted allegations and criticisms of political opponents, and the argumentative-manipulative strategy is directed at a rational explanation of one's own position as the opposite of others. At the same time, each strategy implements corresponding speech acts, subordinated to the particular intention. 


\section{References}

1 Bagautdinov, A. A., Minkin, M. R., Ivanov, A. F. and Nizameeva, A. M. 2018. Language as a Constructor of Social and Cultural Reality. In: X Linguae. European Scientific Language Journal, 11(1), pp. 33-42. https://doi.org/10.18355/ XL.2018.11.01XL.04

2 Baranov, A. N. and Kazakevich, E. G. 1991. Парламентские дебаты: традиции и новаторство [Legislative Debate: Traditions and Innovation]. Moscow: Znanije.

3 Belova, V. F., Zjubina, I. F., Lesnjak, V. V. and Matveeva, G. G. 2016. Универсальный характер коммуникативных стратегий в парламентских дебатах [The universal nature of communication strategies in parliamentary debate]. In: Political Linguistics, 3(57). pp. 53-60.

4 Chudinov, A. Р. 2009. Современная политическая коммуникация [Modern political communication]. Ekaterinburg Uralskij gos. ped. universitet.

5 5. Grice, H. P. 1967. Logic and Conversation. In: Studies in the Way of Words, (ed.) Grice, P, pp. 41-58. Harvard University Press. https://doi. org/10.1163/9789004368811_003

6 Issers, O. S. 2008. Коммуникативные стратегии и тактики русской речи [Communicative strategies and tactics of Russian speech]. Moscow: Editorial URSS.

7 Karasik, V. I. 2004. Языковой круг личность, концепты дискурс [Language circle personality, concepts, discourse]. Moscow: Gnozis.

8 Matveeva, G. G., Zjubina, I. F. and Lesnjak, V. V. 2016. Особенности жанровой системы парламентского дискурса [Features of the genre system of parliamentary discourse]. In: Political Linguistics, 4(58). pp. 133-140.

9 Mihaliova, O. L. 2009. Политический дискурс: специфика манипулятивного воздействия [Political discourse: the specifics of manipulative influence]. Moscow: Editorial URSS.

10 Parshina, 0. N. 2004. Стратегии и тактики речевого поведения современной политической элиты [Strategies and tactics of speech behavior of the modern political elite]. Astrahan': Izd-vo AGTU.

11 Pjetcuh, O. І. 2018. Парламентські дебати Сполученого королівства Великої Британії та Північної Ірландії в когнітивно-дискурсивній парадигмі [Parliamentary Debate of the United Kingdom of Great Britain and the Northern Ireland in Cognitive-Discursive Paradigm]. Cherkasy: Vydavetc Chabanenko Yu. A.

12 Selina, K. A. 2014. Парламентский дискурс как контекст парламентского конфликта [Parliamentary discourse as a context of parliamentary conflict]. In: Grani, 3. pp. 58-63.

13 Sheigal, E. I. 2004. Семиотика политического дискурса [Semiotics of Political Discourse]. Moscow: Gnozis.

14 Vodak, R. 1997. Язык. Дискурс. Политика [Language. Discourse. Politics]. Volgograd: Peremena.

15 Yanko, T. Е. 2001. Коммуникативные стратегии русской речи [Communicative strategies of Russian speech]. Moscow: Yazyki russkoj kultury.

16 Zheltukhina, M. R., Busygina, M. V., Merkulova, M. G., Zyubina, I. A. and Buzinova, L. M. 2018. Linguopragmatic aspect of modern communication: main political media speech strategies and tactics in the USA and the UK. In: X Linguae. European Scientific Language Journal, 11(2), pp. 639-654. https://doi. org/10.18355/XL.2018.11.02.51

17 van Dijk, T. 2015. Дискурс и власть. Репрезентация доминирования в языке коммуникации [Discourse and power. Representation of dominance in communication language]. Moscow: Editorial URSS.

\section{Santrauka}

\section{Natalia V. Kondratenko, Anastasiia A. Kiselova, Liubov V. Zavalska. Parlamentinio diskurso komunikacijos strategijos ir taktika}

Tyrime aptariama pragmatinè lingvistinè parlamentinio diskurso dalyvių (politikų) kalbinès elgsenos analizè ir rezultatų metmenys. Parlamentinis diskursas apibrèžiamas kaip vienas iš politinio diskurso, paremto institucine komunikacija, rūšių. Tyrime pagrindžiamas politinio diskurso žanro heterogeniškumas ir pateikiama debatu (tarp ju - priešrinkiminiu ir parlamentinių debatų) žanro apibrèžtis. Nustatyta, jog parlamentiniai debatai iš esmès atspindi 
pragmatini lingvistini parlamentinio diskurso specifiškumą. Tyrimo duomenys apima Ukrainos parlamento 2004-2019 m. vykusių posèdžių nuorašus. Pagrindinis tipologijos kriterijus buvo stebètu komunikacinių (konfliktinio pobūdžio bei bendradarbiavimą žyminčių) interakciju skiriamieji bruožai. Bendradarbiavimą žyminti komunikacija išsiskyrè naudotomis reguliavimo, informavimo ir tvirtinimo komunikacinèmis strategijomis, o konfliktinio pobūdžio komunikacija - deklaratyvia, konfrontacine ir ginču-kritikos strategijomis.

\section{Nataliia V. Kondratenko}

Dr. Sc. in Philology, Professor at the Department Applied Linguistic, Odesa National University by Mechnykov, Ukraine

\section{Research interests}

Discourse studies, political linguistics, communicative linguistics

\section{Address}

2 Dvorjanska, 65082 Odesa, Ukraine

E-mail

kondr_nat@ukr.net

\section{Anastasiia A. Kiselova}

$\mathrm{PhD}$ in Philology, Associate professor at the Department Applied Linguistic, National University Odessa Law Academy

\section{Research interests}

Discourse studies, political linguistics, communicative linguistics

\section{Address}

23 Fontanska doroga, 65009

Odesa, Ukraine

\section{E-mail}

aakiselyova@gmail.com

\section{Liubov V. Zavalska}

PhD in Philology, Associate professor at the Department Applied Linguistic, National University Odessa Law Academy, Ukraine

\section{Research interests}

Discourse studies, political linguistics, communicative linguistics

\section{Address}

23 Fontanska doroga, 65009

Odesa, Ukraine

\section{E-mail}

L_zavalska@ukr.net 